\title{
Immunofluorescent Localization of Two Different Na,K-ATPases in the Rat Retina and in Identified Dissociated Retinal Cells
}

\author{
Kevin M. McGrail and Kathleen J. Sweadner* \\ Neurosurgical Research, Massachusetts General Hospital, Boston, Massachusetts 02114, and *Department of \\ Physiology, Harvard Medical School, Boston, Massachusetts 02115
}

Two isozymes of the Na,K-ATPase are made in the brain and retina. Antisera have been produced that contain antibodies specific for each of the catalytic subunits of the two isozymes, $\alpha$ and $\alpha(+)$ (Sweadner \& Gilkeson, 1985a). To determine which classes of cells express which form of the Na,K-ATPase, and whether cells can express both forms, the antisera were used to stain sections of the rat retina and dissociated retinal cells by indirect immunofluorescence.

In sections of the retina, bright stain specific for both isozymes was seen in the inner segments of the photoreceptor cells, the outer and inner plexiform layers, and in the ganglion cell axons. Cell bodies were outlined in the inner nuclear layer. Stain specific for the $\alpha$ isozyme was seen in adhering pigment epithelium and at the position of the apical processes of the Müller glial cells. In sections of the optic nerve, the nerve itself stained for both isozymes, although the stain for the $\alpha(+)$ isozyme was stronger. The sheath, in contrast, stained selectively for the $\alpha$ isozyme.

Cells were dissociated from the retina, and they were identified by their morphology and by cell class-specific monoclonal antibodies. Müller glial cells were found to stain brightly for only the $\alpha$ isozyme, while horizontal and ganglion cells stained brightly for both isozymes. Bipolar cells stained faintly for only the $\alpha(+)$ isozyme, while amacrine cells stained faintly for both isozymes. The evidence indicates that different kinds of neurons can express one or both isozymes of the $\mathrm{Na}, \mathrm{K}$-ATPase, and at quantitatively different levels.

The $\mathrm{Na}, \mathrm{K}-\mathrm{ATPase}\left(\mathrm{Na}^{+}\right.$and $\mathrm{K}^{+}$-stimulated adenosine triphosphatase) is a membrane-embedded enzyme responsible for the active transport of $\mathrm{Na}^{+}$and $\mathrm{K}^{+}$in most animal cells. It is present in high concentrations in neurons, where it maintains the ion gradients of $\mathrm{Na}^{+}$and $\mathrm{K}^{+}$necessary for nerve impulses, and in glial cells, which are involved in the buftering of extracellular $\mathrm{K}^{+}$following nerve activity.

When isolated from the kidney, the $\mathrm{Na}, \mathrm{K}$-ATPase is found to contain two protein subunits (Jorgensen, 1982). The larger subunit, $\alpha$, has an apparent molecular weight of approximately

\footnotetext{
Received July 8, 1985; revised Sept. 9, 1985; accepted Sept. 10, 1985.

This work was supported by National Institutes of Health Grants NS 18233 and NS 07009 TS 32. K.J.S. is an Established Investigator of the American Heart Association and a Research Fellow of the Alfred P. Sloan Foundation. Monoclonal antibodies and useful suggestions were generously provided by Drs. C. J. Barnstable, Rockefeller University, and U. C. Dräger, Harvard Medical School. We would also like to thank Drs. R. H. Masland, L. L. Y. Chun, and D. M. D. Landis of Massachusetts General Hospital for many helpful discussions and for the use of their microscopes.

Correspondence should be addressed to Dr. Kevin M. McGrail and Dr. Kathleen J. Sweadner, Wellman 4, Massachusetts General Hospital, Fruit Street, Boston, MA 02114.

Copyright (C) 1986 Society for Neuroscience $0270-6474 / 86 / 051272-12 \$ 02.00 / 0$
}

95,000 Da and contains the site for ATP hydrolysis as well as the site for ouabain binding. The smaller subunit, $\beta$, is a glycoprotein of approximately $40,000 \mathrm{Da}$. Preparations of the Na,KATPase from the brain and the retina demonstrate two biochemically distinct isozymes of the catalytic subunit, called $\alpha$ and $\alpha(+)$ (Sweadner, 1979). These differ in molecular weight by approximately $2000 \mathrm{Da}$ when separated with high-resolution polyacrylamide gel electrophoresis. The $\alpha(+)$ isozyme is also markedly more sensitive to inhibition by ouabain.

The $\alpha$ isozyme is the only form found in kidney and in certain neuronal cells in culture, such as sympathetic neurons from the superior cervical ganglion (Sweadner, 1979) and sensory neurons from the dorsal root ganglion (J. M. Phillips and K. J. Sweadner, unpublished observations). The $\alpha(+)$ form is axonally transported in retinal ganglion cells together with a trace of the $\alpha$ form, while non-neuronal cells of the optic nerve sheath express only the $\alpha$ form (Specht and Sweadner, 1984). Atterwill et al. (1984) suspected that both isozymes were present in separated populations of neurons and glia from the brain, since they observed both high- and low-affinity inhibition by ouabain in both cases. They calculated that contamination was not likely to account for their observations. No single cell type has yet been found to express the $\alpha(+)$ isozyme without at least a trace of the $\alpha$ isozyme.

Polyclonal antibodies specific for the $\alpha$ and $\alpha(+)$ forms of the $\mathrm{Na}, \mathrm{K}-\mathrm{ATPa}$ e have been produced by immunizing rabbits with purified preparations of the $\mathrm{Na}, \mathrm{K}$-ATPases from rat brain stem axolemma and rat renal medulla (Sweadner and Gilkeson, 1985a). It was of immediate interest to look within the CNS for the cellular localization of the two isozymes with these specific antisera. The retina was chosen because of its orderly structure and because much is known about the physiology of its individual cell classes (Rodieck, 1973). Each class of retinal cell (the photoreceptor, bipolar, horizontal, amacrine, ganglion, and Müller glia) can be identified by position, morphology, and unique antigenic determinants. The retina has approximately equal amounts of the two forms of the $\mathrm{Na}, \mathrm{K}$-ATPase (Specht and Sweadner, 1984; Sweadner, 1979), while the adjacent pigment epithelium has only one, the $\alpha$ form (Sweadner, 1979).

By localizing the Na,K-ATPases in the retina we hoped to make the following kinds of distinctions. First, we wanted to know whether the axolemma Na,K-ATPase $[\alpha(+)]$ is located exclusively in neurons and the kidney form $(\alpha)$ exclusively in non-neuronal cells. Second, if the axolemma form of the enzyme were a specialization unique to myelinated axons, it should be expressed only by the ganglion cells: These are the only cells of the retina that have myelinated axons. Third, the photoreceptor dark current requires a $\mathrm{Na}^{+}$gradient maintained by the $\mathrm{Na}, \mathrm{K}$ ATPase. The enzyme is thought to be concentrated in the inner segment, and we hoped to confirm its location and determine whether both isozymes are present. 

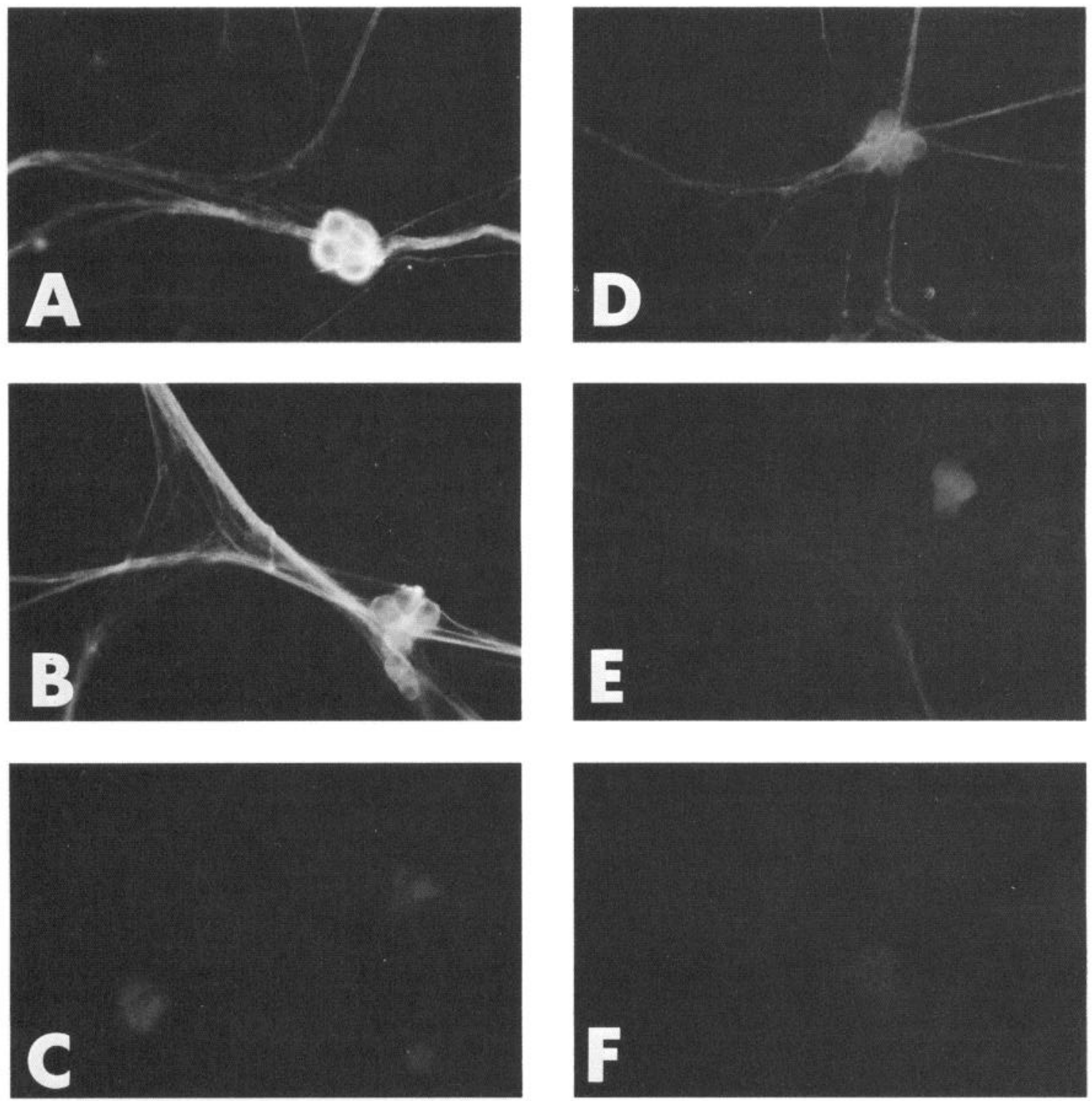

Figure 1. Specificity of the adsorbed A2 and K2 antisera by indirect immunofluorescence with FITC-conjugated goat anti-rabbit IgG second antibody. The antisera to the Na,K-ATPase were used to stain sympathetic neurons from the superior cervical ganglion of the newborn rat, grown in primary cell culture by methods described previously (Sweadner, 1979); these cells express only the $\alpha$ form of the Na.K-ATPase. A, Unadsorbed $\mathrm{K} 2$ antiserum. $B, \mathrm{~K} 2$ antiserum preadsorbed with $\mathrm{Na}, \mathrm{K}$-ATPase $\beta$ subunit purified from brain Na,K-ATPase by chromatography in SDS on a column of Sepharose CL-6B (Sweadner and Gilkeson, 1985a). C, Control rabbit serum. $D$, Unadsorbed A2 antiserum. $E$, A2 antiserum preadsorbed with $\beta$ subunit. $F, \mathrm{~A} 2$ antiserum preadsorbed with microsomes from the renal medulla. Cross-reactive antibodies in A2 were removed by this pretreatment.

\section{Materials and Methods}

\section{Antibodies}

A detailed characterization of the polyclonal antisera used in this study is available in a separate paper (Sweadner and Gilkeson, 1985a). The A2 antiserum was raised against the purified Na,K-ATPase from rat brain stem axolemma, which contains the $\alpha(+)$ form of the enzyme. The K2 antiserum was raised against the purified Na,K-ATPase from rat renal medulla, which contains the $\alpha$ form. In electrophoretic blots of membrane preparations from brain and kidney, the antibodies against the Na,K-ATPase catalytic subunits were specific for either $\alpha$ or $\alpha(+)$, while antibodies directed against the glycoprotein $\beta$ subunits were crossreactive. Cross-reactive antibodies were removed by "cross-adsorption" of antisera, i.e., each antiserum was preadsorbed with unpurified membranes from the heterologous tissue source, with essentially no effect on the titer of binding to the homologous $\mathrm{Na}, \mathrm{K}-\mathrm{ATPa} e$ (Sweadner and Gilkeson, 1985a). Axolemma or kidney microsomes, $100 \mu \mathrm{g}$, were used to cross-adsorb $10 \mu \mathrm{l}$ of $\mathrm{K} 2$ or A2 antisera, respectively, in $100 \mu \mathrm{l}$ of
$0.1 \mathrm{~m}$ phosphate buffer at $4^{\circ} \mathrm{C}$ for $1 \mathrm{hr}$. The cross-reacting antibodies were then pelleted along with the membranes by centrifugation in a Beckman Airfuge for $10 \mathrm{~min}$. Specific antibodies remaining in the supernatant were then used for immunocytochemistry. Microsomes from the renal medulla and axolemma from the brain stem were prepared as described earlier (Sweadner and Gilkeson, 1985a).

We tested the specificity of the A2 and K2 antisera for their ability to stain cells in culture by indirect immunofluorescence, as a further test of the effectiveness of cross-adsorption in removing cross-reactivity. Previous biochemical analysis had demonstrated that sympathetic neurons grown in primary cell culture express only the $\alpha$ form of the catalytic subunit of the Na,K-ATPase (Sweadner, 1979). Neither A2 nor K2 antisera stained these cells prior to fixation and detergent permeabilization (data not shown), indicating that the antigenic determinants must have been exposed only on the inside surface of the cells. Both antisera stained the cells after fixation and permeabilization with Triton X-100, although K2 much more brightly than A2 (Fig. 1, $A$ and $D$ ). If the A2 antiserum were perfectly specific for the axolemma form of the $\mathrm{Na}, \mathrm{K}$ - 
ATPase, it should not have stained these cells. When the antisera were preadsorbed with $\beta$ subunit [purified from a whole-brain Na,K-ATPase preparation by chromatography in SDS on Sepharose CL-6B [Sweadner and Gilkeson, 1985a)], there was little effect on the K2 antiscrum stain of sympathetic neurons (Fig. $1 B$ ), but the stain by $\mathrm{A} 2$ was reduced markedly (Fig. $1 E$ ). When the $\mathrm{A} 2$ antiserum was cross-adsorbed with microsomes from the renal medulla, which contain $\alpha$ and $\beta$, its ability to stain sympathetic neurons was reduced to control levels (Fig. $1 F$ ). Thus, cross-adsorption with membranes from the heterologous tissue source was used routinely to remove cross-reactive antibodies in the antisera.

Descriptions of the cell class-specific monoclonal antibodies used in this study have been published previously (Barnstable and Dräger, 1984; Barnstable et al., 1983, 1985; Dräger et al., 1983, 1984).

\section{Tissue preparation}

Cryostat sections, $12-15 \mu \mathrm{m}$, of rat retinas fixed with paraformaldehyde or paraformaldehyde plus picric acid were the generous gift of Dr. Ursula C. Dräger, Harvard Medical School. In the particular experiments chosen for the figure, a pigmented rat was used that had been fixed with paraformaldehyde using the "pH change" method (Berod et al., 1981), which caused the pigment epithelium to adhere to the tips of the outer segments of the photoreceptors during tissue preparation. Pieces of optic nerve were sectioned in the same blocks.

Dissociation of the retina was carried out according to the procedure described by Sarthy and Lam (1979). Albino rats were anesthetized with ether and killed by cardiac aspiration. The eyes were enucleated and hemisected just posterior to the ora serata. The posterior eyecups were incubated in $0.2 \mathrm{mg} / \mathrm{ml}$ of hyaluronidase (Type III, H-2251; Sigma Chemical Co., St. Louis, MO) and $1.0 \mathrm{mg} / \mathrm{ml}$ of collagenase (Type II, C-6885; Sigma) in mammalian Ringer's solution for $15 \mathrm{~min}$ at $37.5^{\circ} \mathrm{C}$. The composition of the Ringer's solution was $125.4 \mathrm{mM} \mathrm{NaCl}, 3.6 \mathrm{~mm}$ $\mathrm{KCl}, 1.2 \mathrm{~mm} \mathrm{MgCl}, 22.6 \mathrm{~mm} \mathrm{NaHCO}, 0.1 \mathrm{~mm} \mathrm{NaH} \mathrm{PO}_{4}, 0.4 \mathrm{~mm}$ $\mathrm{Na}_{2} \mathrm{HPO}_{4}, 1.2 \mathrm{mM} \mathrm{Na} 2 \mathrm{SO}_{4}, 1.15 \mathrm{mM} \mathrm{CaCl}_{2}$, and $10 \mathrm{~mm}$ glucose. The eyecups were then washed in the Ringer's solution and incubated for $25 \mathrm{~min}$ at $37.5^{\circ} \mathrm{C}$ in $1 \mathrm{ml}$ of $\mathrm{Ca}^{+2}$-free Ringer's solution containing 20 $\mu l$ of papain, $12 \mathrm{U} / \mathrm{mg}, 37 \mathrm{mg} / \mathrm{ml}$ (catalog no. 3126; Worthington/ Cooper Biomedical, Malvern, PA), $2.5 \mathrm{~mm}$ EGTA, and $0.5 \mathrm{mg}$ cysteine $\mathrm{HCl}$. The eyecups were again washed with Ringer's solution and incubated in $1 \mathrm{mg}$ DNase I (Type I, D-4763; Sigma) and $1 \%$ BSA in Ringer's. After 5 min at $37.5^{\circ} \mathrm{C}$, the retinas were triturated gently with a wide-bore, fire-polished Pasteur pipette. The solution became cloudy with cell suspension, and large clumps of cells were allowed to settle over a 5 min period. The cell-containing supernatant was aspirated and placed on ice. One milliliter of $1 \%$ BSA in Ringer's was added to the remaining retina and the trituration was repeated. The entire process was repeated several times with increasingly vigorous trituration.

The dissociated cells in the BSA-containing mammalian Ringer's solution were gently pelleted for $10 \mathrm{~min}$ in a Beckman Microfuge 11 at $1500 \mathrm{rpm}$. The clear supernatant was aspirated, and the cells were resuspended by extremely gentle trituration using a small-bore, firepolished Pasteur pipette in 2\% paraformaldehyde in $0.1 \mathrm{M}$ phosphate buffer, $\mathrm{pH} 7.4$. Cells were fixed in this solution for $30 \mathrm{~min}$ at room temperature and then pelleted by centrifugation as before. The fixative was aspirated, and the cells were resuspended in $0.1 \mathrm{M}$ phosphate buffer, $\mathrm{pH} \mathrm{7.4}$, and stored at $4^{\circ} \mathrm{C}$ until used for immunocytochemistry. They retained morphologic integrity and antigenicity for at least 2 weeks. For immunocytochemistry, a drop of the cell-containing solution was spread by tilting on a glass slide that had been thinly coated with $1 \%$ agarose heated to $70^{\circ} \mathrm{C}$. The slides were allowed to air-dry at room temperature for $15 \mathrm{~min}$, after which the cells adhered firmly to the agarose gel.

\section{Immunofluorescence}

Dilutions of all antibodies used in these studies were in a solution of $0.3 \%$ Triton X-100 and $2.5 \%$ goat serum in $0.1 \mathrm{~m}$ phosphate buffer, $\mathrm{pH}$
7.22. The same solution was also used for the washes. The $A 2$ and $K 2$ antisera and normal rabbit serum controls were used at 1:200 dilutions with $1 \%$ rat serum added to decrease nonspecific binding. Monoclonal antibodies Ret-B1, anti-glial filament I, anti-glial filament II, and anti$200 \mathrm{~K}$ neurofilament (R3) were used undiluted as hybridoma culture supernatants. Other antibodies were diluted as follows: $2 \mathrm{Gl} 2,1: 500$; HPC-1, 1:10; anti-150K neurofilament mouse antiserum, 1:250.

Essentially the same staining procedure was used for sections adhering to gelatin-coated slides and for dissociated cells adhering to agarose. Slides were covered with the Triton and goat serum-containing solution for $30 \mathrm{~min}$ at room temperature. (Prior to incubation with cell-specific Ret-B1 antibody, the same solution was used but without Triton.) The slides were incubated with the cell-specific antibodies for $1 \mathrm{hr}$ at room temperature, followed by five $5 \mathrm{~min}$ washes. Slides were then incubated with cross-adsorbed $\mathrm{A} 2$ or $\mathrm{K} 2$ antisera for $1 \mathrm{hr}$ at room temperature, followed by five $10 \mathrm{~min}$ washes. Double-labeling by indirect immunofluorescence was carried out by incubating the slides with goat antirabbit IgG and goat anti-mouse IgG, IgM, IgA [fluoresein isothiocyanate- (FITC-) or rhodamine-conjugated] in 1:100 dilutions for $1 \mathrm{hr}$ at room temperature, followed by five $5 \mathrm{~min}$ washes. The fluorescent second antibodies were obtained from Boehringer Mannheim Biochemicals (Indianapolis, IN), or Cappel/Cooper Biomedicals (Malvern, PA). Slides of sections were mounted in glycerol containing $9 \mathrm{~mm} p$-phenylenediamine, $15 \mathrm{~mm} \mathrm{NaCl}$, and $1 \mathrm{~mm}$ Tris $\mathrm{Cl}$, pH 8.0; slides of dissociated cells were mounted in Tris-buffered saline, $\mathrm{pH}$ 8.5.

\section{Results}

\section{Sections of the rat retina}

The A2 and $\mathrm{K} 2$ antisera were used to stain paraformaldehydefixed, detergent-treated cryostat sections of the rat retina (Fig. 2 ). Figure $2 A$ shows the phase-contrast image of a retinal section, while Figure $2 A^{\prime}$ is a bright-field image, in which pigment granules can be seen in pigment epithelium adhering to the tips of the outer segments. Figure $2 B$ shows the result of staining the sections with control rabbit serum, followed by rhodamineconjugated goat anti-rabbit IgG second antibody. Unadsorbed $\mathrm{K} 2$ (Fig. 2C) and A2 (Fig. 2F) antisera showed a similar staining pattern. The pattern confirmed the observations of Stahl and Baskin (1984), who used an antiserum that reacts with both forms of the Na,K-ATPase. Brightest stain was in the inner segments of the photoreceptors, the outer and inner plexiform layers, and in bundles of ganglion cell axons (Fig. 2, $C$ and $F$ ). No stain of the outer segments of the photoreceptors was seen with either antiserum, but adhering pigment epithelium was stained. In other experiments in which no adhering pigment granules could be seen, there was also no stain at the tips of the outer segments.

When the labeling was repeated using antisera that had been preadsorbed with purified Na,K-ATPase (K2 with purified kidney $\mathrm{Na}, \mathrm{K}-\mathrm{ATPase}$, and $\mathrm{A} 2$ with purified axolemma $\mathrm{Na}, \mathrm{K}-$ ATPase), the stain was greatly reduced in both cases (preadsorbed K2, Fig. $2 D$; preadsorbed A2, Fig. $2 G$ ).

When the labeling was repeated using cross-adsorbed antisera, differences in the pattern of staining became evident (Fig. 2, $E$ and $H$ ). Bright stain specific for the $\alpha(+)$ isozyme continued to be found in the inner segments of photoreceptors, the outer and inner plexiform layers, and in bundles of ganglion cell axons (Fig. $2 H$ ). Vertical ribbons of fluorescence were also seen in the outer nuclear layer, and cell bodies were outlined in the inner nuclear layer. Stain specific for the $\alpha$ isozyme was found in the

Figure 2. Localization of the Na,K-ATPase isozymes in sections of the rat retina. Fixed cryostat sections of the retina were permeabilized with Triton X-100 and stained with antisera before and after cross-adsorption. $A$, Phase-contrast image of a retinal cross section. $A^{\prime}$, Bright-field image, in which pigment granules can be seen at the tips of the outer segments of the photoreceptors. $B-H$, Fluorescence photomicrographs in which rhodamine-conjugated goat anti-rabbit IgG was the second antibody. $B$, Control rabbit serum; $C$, unadsorbed $\mathrm{K} 2$ antiserum; $D, \mathrm{~K} 2$ antiserum preadsorbed with purified kidney $\mathrm{Na}, \mathrm{K}-\mathrm{ATPase} ; E, \mathrm{~K} 2$ antiserum cross-adsorbed with axolemma membranes. Blood vessels cut in cross section were stained by the $\mathrm{K} 2$ antiserum; this was attributed to contaminating antibodies against a protein unrelated to the Na,K-ATPase (Sweadner and Gilkeson, 1985b). $F$, Unadsorbed $\mathrm{A} 2$ antiserum; $G, \mathrm{~A} 2$ antiserum preadsorbed with purified axolemma Na,K-ATPase; $H, \mathrm{~A} 2$ antiserum cross- 

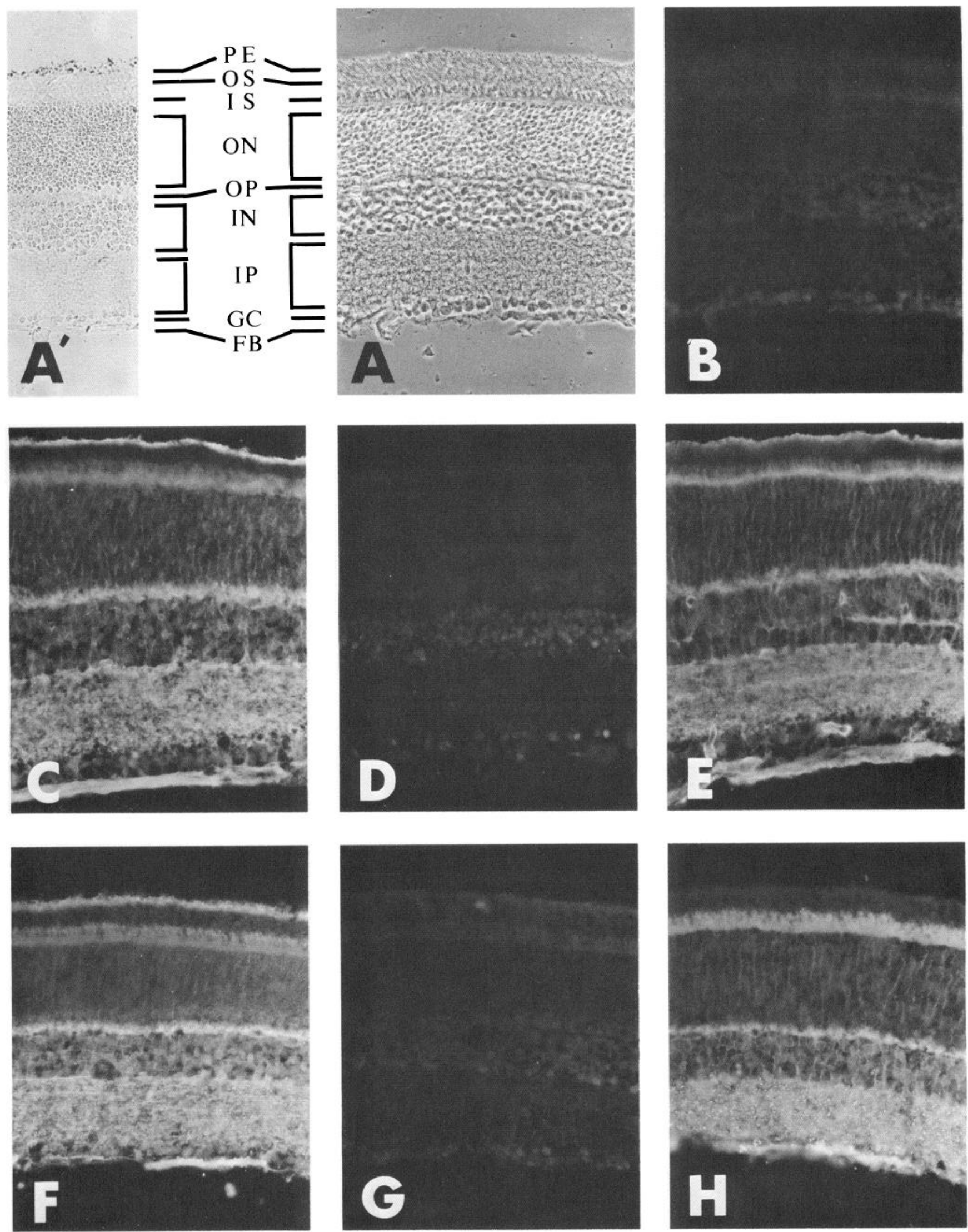

adsorbed with kidney membranes. The layers of the retina are marked as follows: $P E$, pigment epithelium; $O S$, outer segments of the photoreceptors; $I S$, inner segments of the photoreceptors; $O N$, outer nuclear layer, the site of photoreceptor cell bodies; $O P$, outer plexiform layer, a synaptic zone; $I S$, inner segments of the photoreceptors; $O N$, outer nuclear layer, the site of photoreceptor cell bodies; $O P$, outer plex $I N$, inner nuclear layer, the site of the cell bodies of horizontal cells, bipolar cells, Muner of ganglion cells and the displaced amacrine cells; $F B$, fiber bundles of ganglion cell axons. 

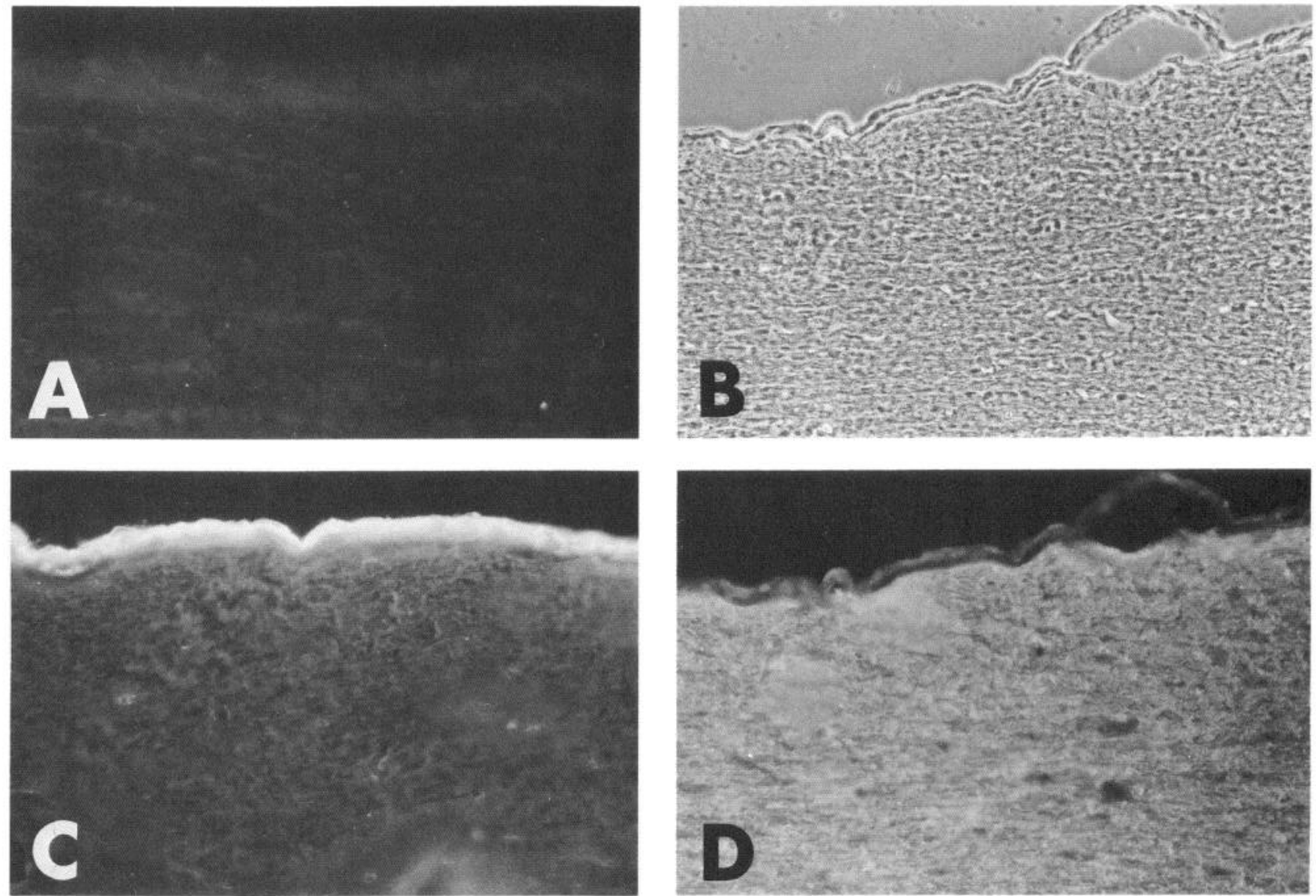

Figure 3. Localization of the Na,K-ATPase isozymes in longitudinal sections of the optic nerve from the orbit-chiasm segment. A, Control rabbit serum, followed by rhodamine-conjugated goat anti-rabbit antiserum. $B$, Phase-contrast image, in which a portion of the sheath was fortuitously pulled away from the optic nerve. $C, \mathrm{~K} 2$ antiserum cross-adsorbed with axolemma membranes stained the $\alpha$ isozyme of the Na,K-ATPase. $D$, A2 antiserum cross-adsorbed with kidney membranes stained the $\alpha(+)$ isozyme.

inner segment layer, the outer and inner plexiform layers, in bundles of ganglion cell axons, and around cell bodies (Fig. $2 E$ ). The inner segment layer stain was relatively fainter in the outer portions of the inner segments, however, and much brighter at their bases, where Müller glial cells have interdigitating processes. In addition, the adhering pigment epithelium was stained by the cross-adsorbed $\mathrm{K} 2$ antiserum (Fig. $2 E$ ), and not by the cross-adsorbed A2 antiserum (Fig. $2 H$ ). This confirms the prior biochemical demonstration of the presence of only the $\alpha$ form of the Na,K-ATPase in pigment epithelium isolated from the frog retina (Sweadner, 1979). The bundles of ganglion cell axons were stained more brightly by the $\mathrm{A} 2$ antiserum than by the $\mathrm{K} 2$ antiserum. Blood vessels were also stained by the $\mathrm{K} 2$ antiserum (Fig. 2E); we believe this stain to be due to unrelated antibodies contaminating the antiserum, since it was not reduced by preadsorption with purified Na,K-ATPase (Sweadner and Gilkeson, 1985b).

\section{Sections of the rat optic nerve}

Sections of optic nerve were stained on the same slides with the retinal sections. Figure $3 B$ shows the phase-contrast image of the optic nerve, while Figure $3 A$ was the result of staining with control rabbit serum. Faint counterstaining of the non-neuronal cell nuclei by the mounting medium can be seen. Figure $3 C$ shows the stain observed with cross-adsorbed $\mathrm{K} 2$ antiserum; the nerve sheath was brightly stained for the $\alpha$ form of the Na,KATPase, while the optic nerve itself was stained less intensely. Figure $3 D$ shows the stain observed with the cross-adsorbed A2 antiserum; the sheath was not stained, while the nerve was stained brightly for the $\alpha(+)$ form. It was not possible at this resolution to distinguish the staining of nerve and glia. Preadsorption of the antisera with the homologous purified $\mathrm{Na}, \mathrm{K}$ ATPases greatly reduced the stain (not shown).

\section{Dissociated retinal cells}

Despite the stratified organization of the retina, every layer has contributions of somas or processes from two or more cell classes. Because the staining of closely apposed neuronal and glial processes cannot be distinguished in sections in the light microscope (LM), the examination of sections alone does not allow the assignment of the enzyme in any layer to a particular cell class. For this reason we also stained dissociated cells, identified by their morphology and by cell class-specific monoclonal antibodies.

With practice, dissociation of the rat retina by the technique of Sarthy and Lam (1979) yielded large numbers of single cells. A majority of the cells were unidentifiable spheres, but a significant number of photoreceptors, Müller cells, bipolar cells, horizontal cells, amacrine cells, and ganglion cells could be identified by their unique morphologies. The photoreceptor cells, however, underwent marked deterioration in their appearance following manipulation and fixation. All of the following observations were consistently reproducible and were obtained with many dissociated cells. Both $\mathrm{A} 2$ and $\mathrm{K} 2$ antisera were cross-adsorbed prior to use, and controls demonstrated that preadsorption of the antisera with purified $\mathrm{Na}, \mathrm{K}-\mathrm{ATPases}$ of the homologous type eliminated the specific stain.

Müller cells were easily identified (Fig. 4, $A$ and $D$ ). They 

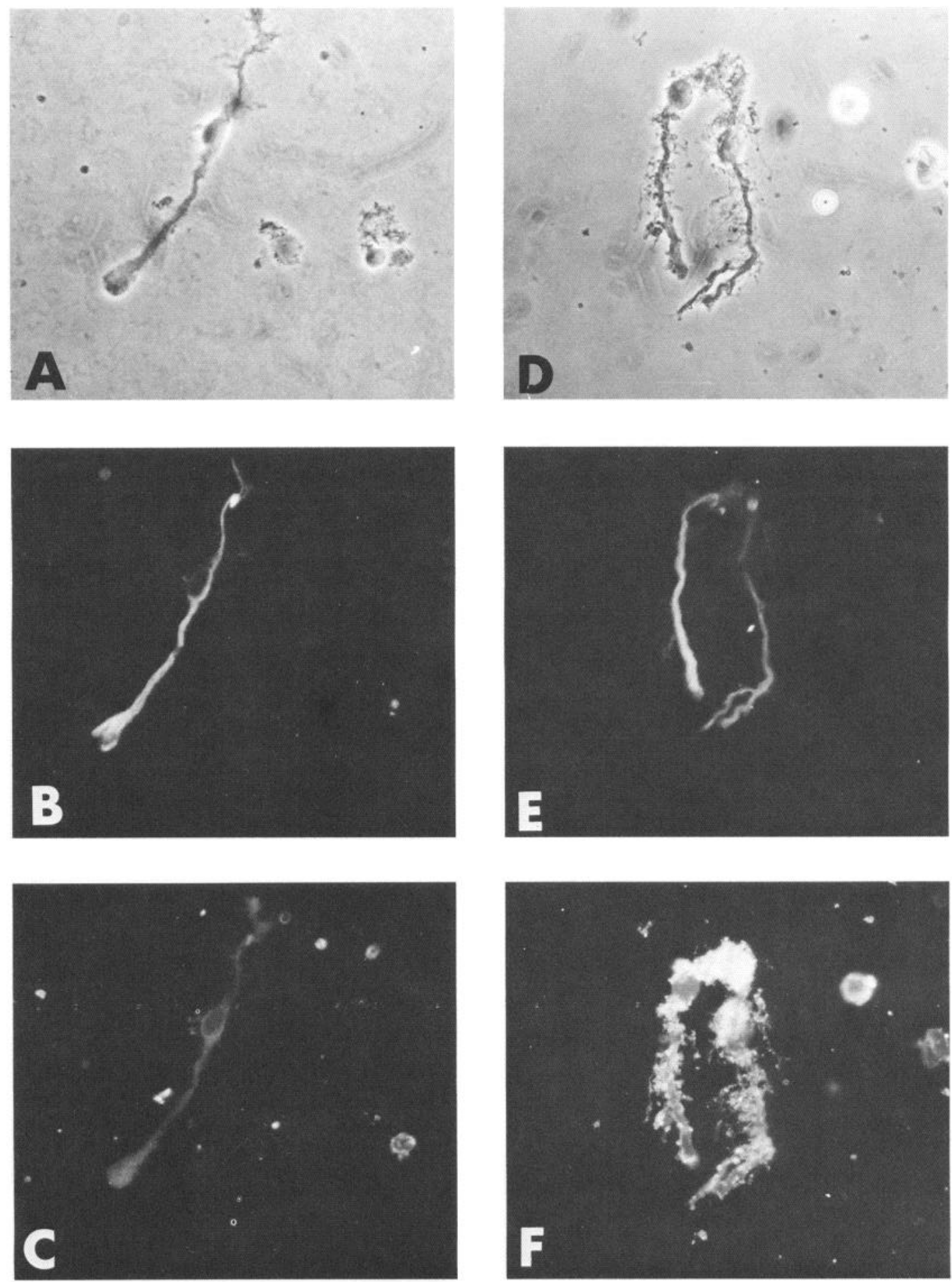

Figure 4. Double-label immunofluorescence of Müller cells. These and the following figures illustrate dissociated cells labeled with cross-adsorbed rabbit antibodies against the $\mathrm{Na}, \mathrm{K}-\mathrm{ATPase}$ and mouse monoclonal antibodies against other cell antigens. In each figure, phase-contrast pictures of the cells are shown first, then the stain seen with cell-specific monoclonal antibodies, and, finally, the stain seen with the antibodies against the Na,K-ATPase (A2, left; K2, right). $A$ and $D$, Phase-contrast photomicrographs of Müller cells. Two attached Müller cells were seen in $D$. B and $E$, Müller cells labeled with anti-glial filament I monoclonal antibody, followed by FITC-conjugated goat anti-mouse (IgG, IgM, IgA) second antibody, demonstrating specific labeling of the cytoskeleton. $C$, Müller cell labeled with A2 antiserum followed by rhodamine-conjugated goat anti-rabbit IgG second antibody. Fluorescence observed with A2 was never greater than that observed with control rabbit serum. The cell in this photograph had few hairlike lateral processes but was chosen because of its bright labeling with anti-glial filament I antibody. In many other Müller cells with larger numbers of these processes, A2 was never found to produce labeling. $F$, Two Müller cells labeled with K2 followed by rhodamineconjugated goat anti-rabbit IgG second antibody. Bright labeling for the $\alpha$ isozyme of the Na,K-ATPase was present in Müller cells and appeared especially intense in the lateral processes. 

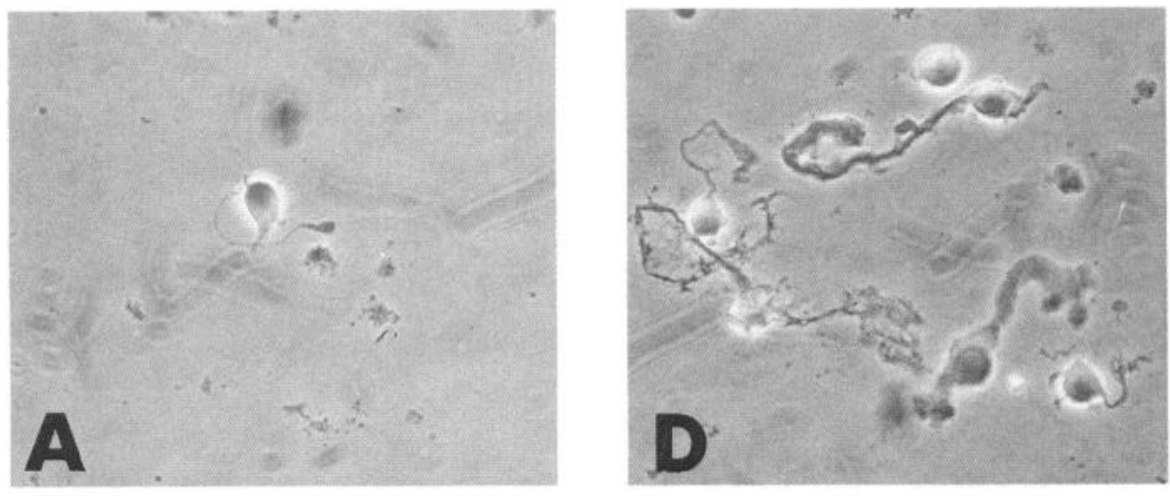

Figure 5. Double-label immunofluorescence of bipolar cells. $A$ and $D$, Phasecontrast photomicrographs of bipolar cells and Müller cells. $B$ and $E$, Bipolar cells labeled with Ret-B1 monoclonal antibody (specific for bipolar cells and the inner segments of photoreceptors) followed by rhodamine-conjugated goat anti-mouse (IgG, IgM, IgA) second antibody, $C$, Bipolar cell labeled with $\mathrm{A} 2$ antiserum followed by FITC-conjugated goat anti-rabbit IgG second antibody. Labeling for the $\alpha(+)$ isozyme of the $\mathrm{Na}, \mathrm{K}-\mathrm{ATPase}$ was slightly greater than control; this was consistently demonstrated in bipolar cells with the A2 antiserum. $F$, Bipolar cells and Müller cells labeled with the $\mathrm{K} 2$ antiserum followed by FITC-conjugated goat antirabbit IgG second antibody. Labeling of bipolar cells with $\mathrm{K} 2$ was never greater than that seen with control rabbit serum. In contrast, Müller glial cells labeled brightly for the $\alpha$ isozyme of the Na,K-ATPase.
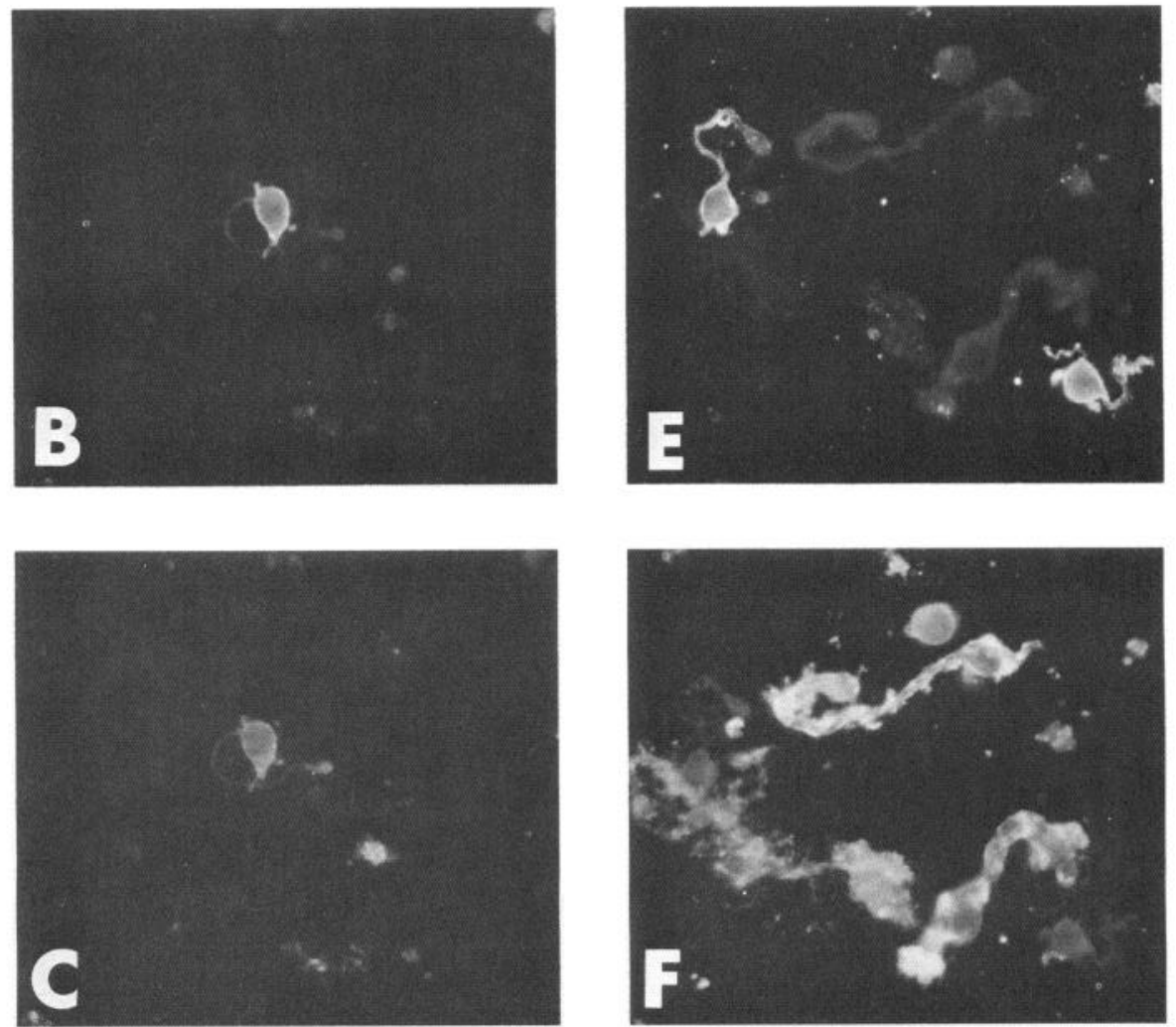

were large and elongated, with a centrally placed nucleus and multiple hairlike lateral processes. They were labeled by monoclonal antibodies against glial filaments-anti-GF I and antiGF II (C. J. Barnstable, personal communication)-or against glial fibrillary acidic protein - anti-GFAP (Bignami and Dahl, 1979). When double labeling was carried out using anti-GF I antibody and the A2 and K2 antisera (Fig. 4), the Müller cells stained only for the $\alpha$ isozyme of the $\mathrm{Na}, \mathrm{K}$-ATPase, and that staining was brightest in the membrane of the lateral processes. Staining for $\alpha(+)$ was never greater than that seen with control rabbit serum. Müller cells exhibited slightly greater nonspecific cytoplasmic staining when control rabbit serum was used than other classes of cells, which may reflect the presence of spurious antibodies against intermediate filaments present in the sera of many rabbits even before immunization (Osborn et al., 1977).

Bipolar cells had a small cell body, which gave rise to two dendritic tufts and a long axon that ended in a terminal bulb (Fig. 5, $A$ and $D$ ). Monoclonal antibody Ret-B1, which specifically labels bipolar cells and the inner segments of photoreceptors (Barnstable et al., 1983), stained these cells brilliantly and with high specificity. Double labeling of the bipolar cells with
Ret-B1 antibody and A2 and K2 antisera showed the cells to express no detectable $\alpha \mathrm{Na}, \mathrm{K}$-ATPase isozyme (Fig. $5 F$ ) but to express faint staining for the $\alpha(+)$ isozyme that was consistently greater than control (Fig. $5 C$ ).

Horizontal cells (Fig. 6) had somas intermediate in size between those of amacrine cells and those of the large retinal ganglion cells. They had five or more irregular and thick processes, which emanated from the entire circumference of the cell soma. A number of attempts were made to label these cells with anti-200K and anti-150K neurofilament antibodies - both known to label the axonless subclass of horizontal cells (Dräger et al., 1983, 1984) without success. This indicates the absence of that subclass of horizontal cell in the dissociate, or the loss of the antigenic determinants. The cell types pictured in Figure 6 never stained with the HPC-1 (anti-amacrine cell) or 2 G12 (anti-ganglion cell) antibodies, or any of the other markers used. Brilliant staining with both $\mathrm{A} 2$ and $\mathrm{K} 2$ antisera was consistently seen in these cells, indicating high concentrations of both isozymes of the $\mathrm{Na}, \mathrm{K}-\mathrm{ATPase}$.

Amacrine cells had a small cell body and a dendritic arborization emanating from one pole. A subpopulation of these 

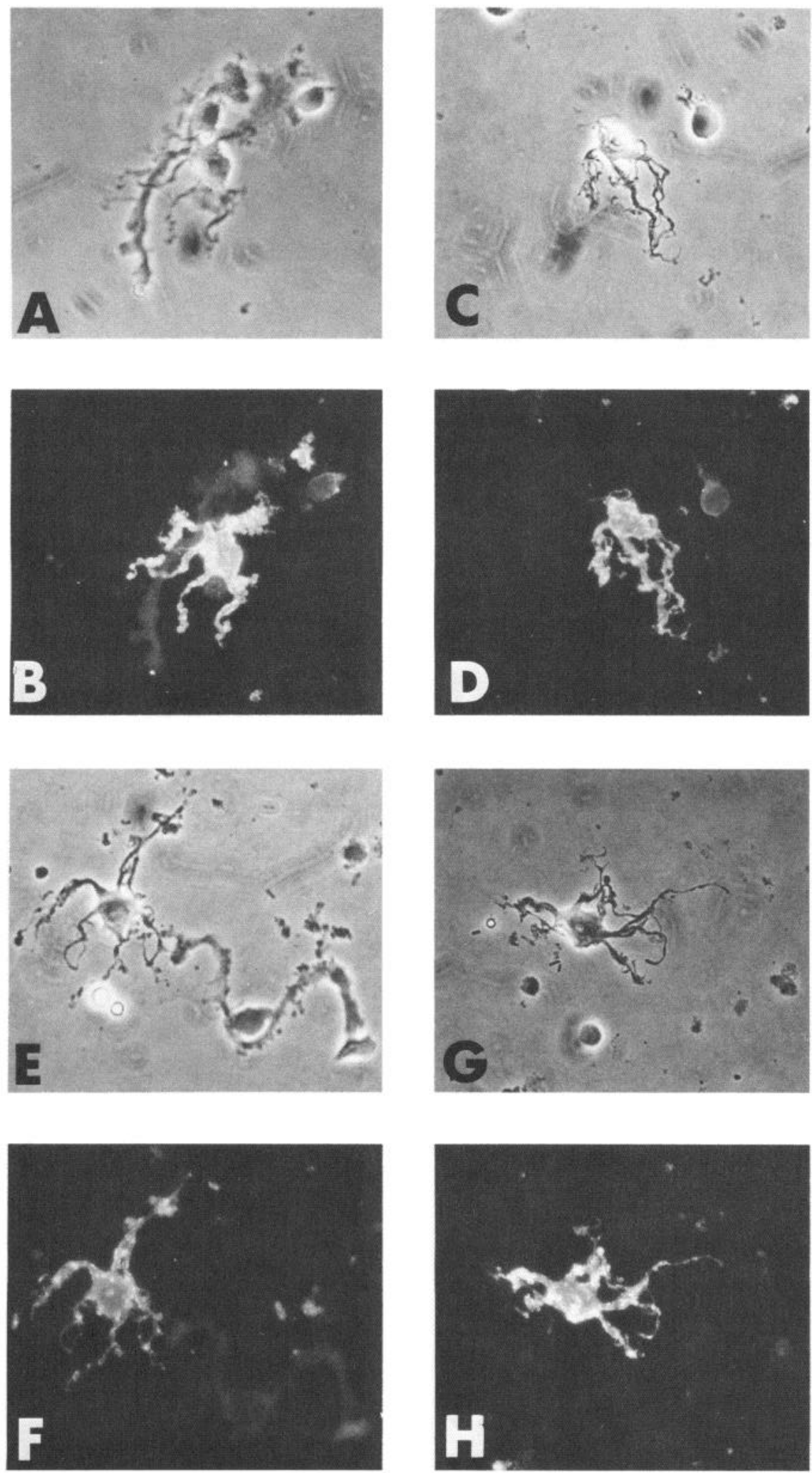

Figure 6. Immunofluorescent labeling of both isozymes of the $\mathrm{Na}, \mathrm{K}$ ATPase in horizontal cells. Since no monoclonal markers were found to identify this class of cells, only phasecontrast photomicrographs documenting their characteristic morphology are shown, along with their fluorescent stain with the $\mathrm{A} 2$ and $\mathrm{K} 2$ antisera. $A, C, E$, and $G$, Phase-contrast photomicrographs. $B$ and $F$, Immunofluorescence obtained with the A2 antiserum, followed by FITC- or rhodamine-conjugated goat anti-rabbit IgG second antibody. $D$ and $H$, Immunofluorescence obtained with the K2 antiserum. Müller cells, which did not label with the A2 antiserum, are also seen $(B, F)$. cells (Fig. 7) was labeled by monoclonal antibody HPC-1, which is specific for a subclass of amacrine cells in the rat retina (Barnstable et al., 1985). These cells stained lightly with both A2 and $\mathrm{K} 2$, indicating the presence of both the $\alpha$ and $\alpha(+)$ isozymes of the Na,K-ATPase. Similar staining was seen in cells morphologically identified as amacrine cells but without reactivity to HPC-1.
Ganglion cells were distinguished by their large somas and the presence of four or fewer processes, which tended to be less varicose than those of the horizontal cells (Fig. 8). These cells labeled brightly and specifically with monoclonal antibody $2 \mathrm{G} 12$, which is against the Thy-1 antigen (Barnstable and Dräger, 1984). When incubated with $\mathrm{A} 2$ and $\mathrm{K} 2$ antisera, ganglion cells stained brightly for both the $\alpha$ and $\alpha(+)$ isozymes of the Na,K-ATPase. 

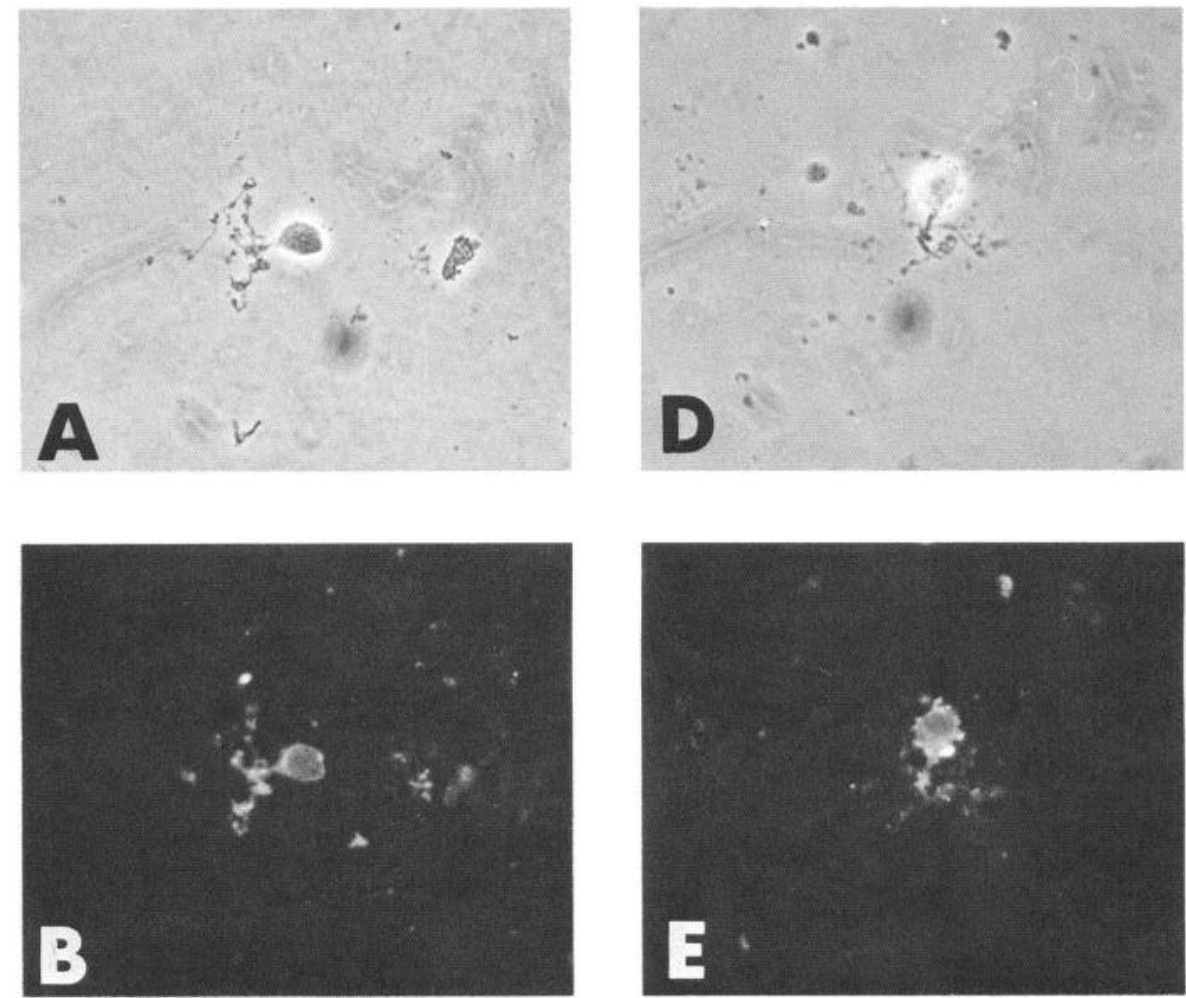

Double-label immunofluorescence of amacrine cells. $A$ and $D$, Phase-contrast photomicrographs. $B$ and $E$, Amacrine cells labeled with HPC-1 monoclonal antibody, specific for a subpopulation of amacrine cells, followed by FITC-conjugated goat antimouse (IgG, IgM, IgA) second antibody. $C$, Amacrine cell labeled with $\mathrm{A} 2$ antiserum followed by rhodamine-conjugated goat anti-rabbit IgG second antibody. Faint labeling, slightly greater than control rabbit serum, was consistently seen for the $\alpha(+)$ isozyme of the $\mathrm{Na}, \mathrm{K}-\mathrm{ATPase}$. $F$, Amacrine cell labeled with $\mathrm{K} 2$ antiserum followed by rhodamine-conjugated goat anti-rabbit IgG second antibody. Faint to moderate labeling for the $\alpha$ isozyme of the $\mathrm{Na}, \mathrm{K}-\mathrm{ATPase}$ was also seen consistently.
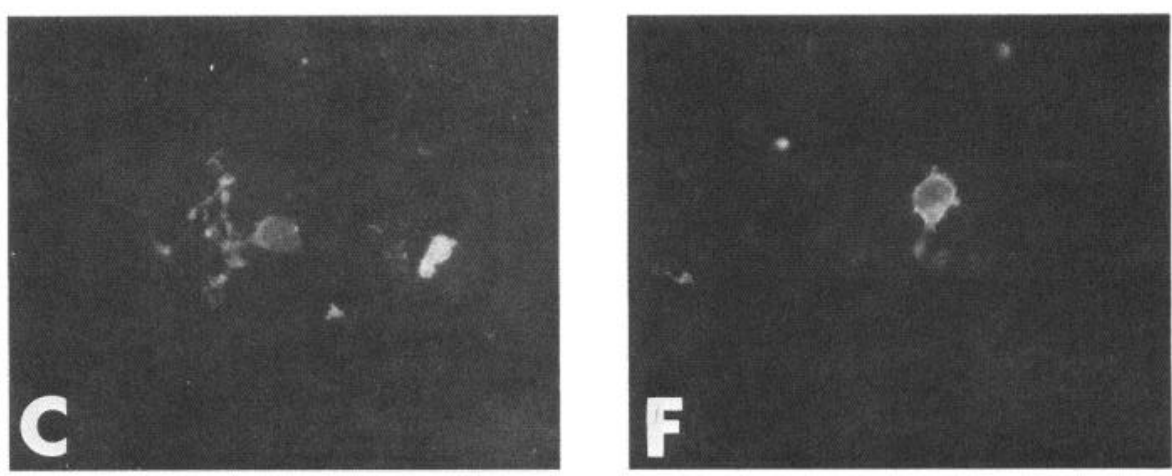

There were also tangles of processes that might have been broken-off portions of the plexiform layers, which stained brightly with both $\mathrm{A} 2$ and $\mathrm{K} 2$ antisera (not shown). These structures did not label with any of the cell-specific monoclonal antibodies.

\section{Discussion}

\section{Localization of the Na,K-ATPase in retinal sections}

The two isozymes of the $\mathrm{Na}, \mathrm{K}-\mathrm{ATP}$ ase are present in the retina in approximately equal amounts by biochemical criteria (Specht and Sweadner, 1984; Sweadner, 1979). Our results indicate that most neurons in the retina express both isozymes, and both contribute heavily to the bright stain of the photoreceptor inner segment layer and the plexiform layers. The Müller glial cells stain for only the $\alpha$ form of the Na,K-ATPase, but they span most layers of the retina and contribute stain to the plexiform layers with their lateral processes. A band of stain for the $\alpha$ form of the $\mathrm{Na}, \mathrm{K}-\mathrm{ATPase}$ at the base of the inner segments suggests a concentration of $\mathrm{Na}, \mathrm{K}-\mathrm{ATPase}$ in the apical processes of the Müller cells, which interdigitate with the photoreceptor inner segments. The pigment epithelium contains only the $\alpha$ isozyme of the Na,K-ATPase.

Unlike the photoreceptors of lower vertebrates, which are stout and sturdy, the photoreceptors of mammals are long and thin and collapse after dissociation, even in the presence of fixative. Consequently, we were unable to examine dissociated photoreceptor cells with well-preserved morphology to verify that the more distal stain for the $\alpha$ isozyme in the inner segment layer was in fact in inner segments and not in glial processes; in this case, electron microscopic immunocytochemistry would be very advantageous.

Previous investigators have studied the localization of the $\mathrm{Na}, \mathrm{K}-\mathrm{ATP}$ ase in the retina using techniques including assay of $\mathrm{Na}, \mathrm{K}-\mathrm{ATP}$ ase activity in subcellular fractions (Zimmerman et al., 1976), ${ }^{3} \mathrm{H}$-ouabain autoradiography (Stirling and Lee, 1980; Stirling and Sarthy, 1985), $\mathrm{K}^{+}$-dependent $p$-nitrophenyl phosphatase activity (a specific partial reaction of the $\mathrm{Na}, \mathrm{K}$-ATPase that can be visualized in the electron microscope by the precipitation of released inorganic phosphate with lead or strontium) (Ueno et al., 1980, 1981), and immunofluorescence with cross-reactive anti-Na,K-ATPase antibodies (Stahl and Baskin, 1984). There is general agreement that the highest levels of $\mathrm{Na}, \mathrm{K}-\mathrm{ATP}$ ase are in the photoreceptor inner segments, where active transport of $\mathrm{Na}^{+}$is thought to power the photoreceptor dark current, and in the plexifom layers, where most of the 

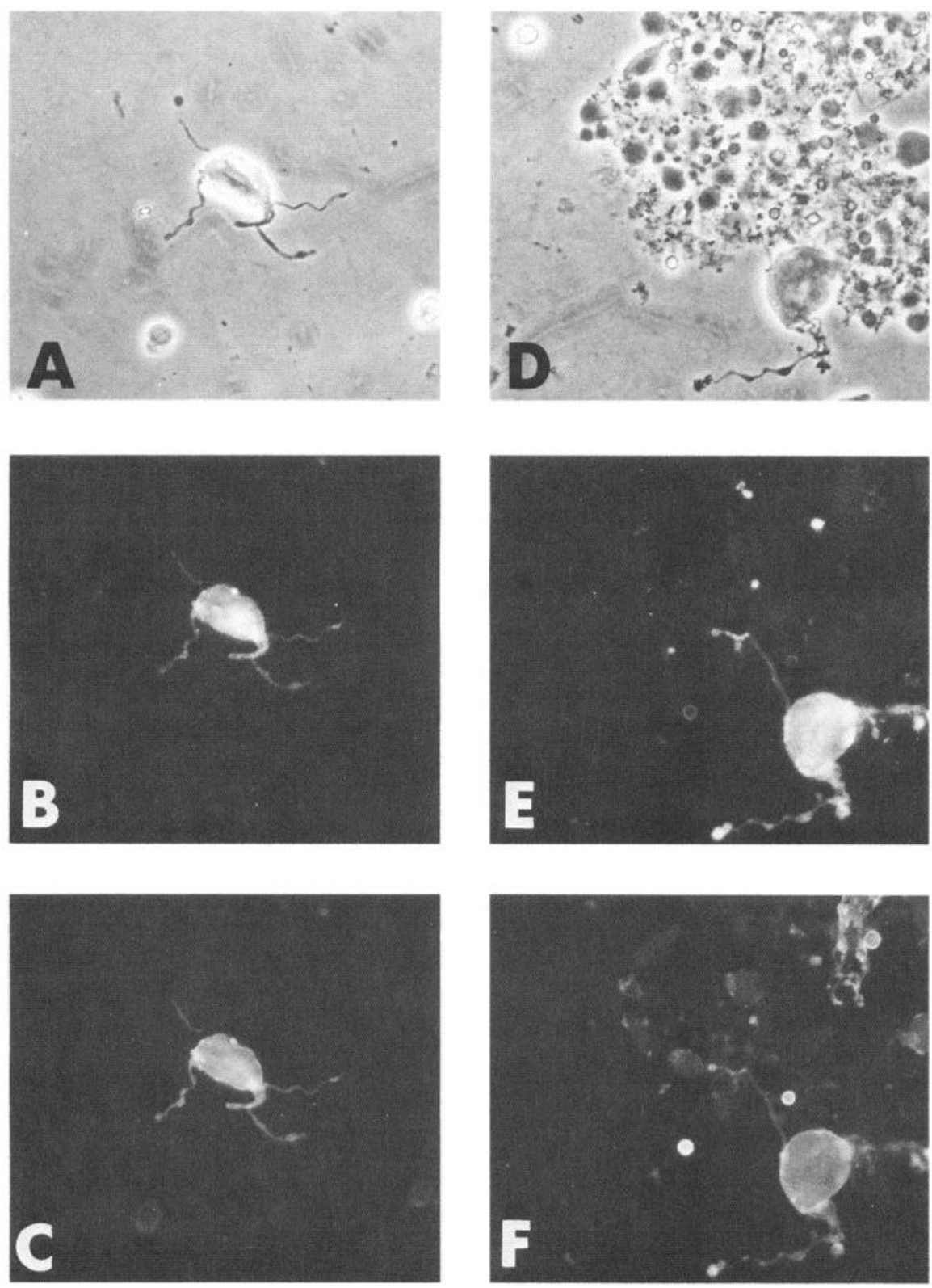

Figure 8. Double-label immunofluorescence of ganglion cells. $A$ and $D$, Phase-contrast photomicrographs. $B$ and $E$, Ganglion cells labeled with $2 \mathrm{G} 12$ monoclonal antibody against the Thy-1 antigen, which is specific for ganglion cells in the retina, followed by rhodamine-conjugated goat anti-mouse (IgG, IgM, IgA) second antibody. Bright labeling of retinal ganglion cells and a clear lack of labeling of surrounding material was seen. $C$, Ganglion cell labeled with A2 antiserum followed by FITC-conjugated goat anti-rabbit IgG second antibody. $F$, Ganglion cell labeled with $\mathrm{K} 2$ antiserum followed by FITC-conjugated goat anti-rabbit IgG second antibody. Bright labeling of both of the $\mathrm{Na}, \mathrm{K}-\mathrm{ATPase}$ isozymes was seen in these cells. Bright labeling for the $\alpha$ isozyme in a portion of a horizontal cell was also seen in $F$ (upper right); this was not labeled by $2 \mathrm{G} 12$ in $E$.

synapses of the retina are made and where neuronal processes have a very high surface-to-volume ratio. None of the above techniques for localization of the $\mathrm{Na}, \mathrm{K}-\mathrm{ATPase}$ is able to distinguish between the two Na,K-ATPase isozymes, however.

\section{Localization of the Na,K-ATPase in sections of the optic nerve}

Previous studies indicated that the form of the Na,K-ATPase made in retinal ganglion cells and transported to the optic nerve was predominantly the $\alpha(+)$ isozyme, while the oligodendrocytes and other cells of the optic nerve sheath made the $\alpha$ isozyme (Specht and Sweadner, 1984). The specific antibody stain of optic nerve sections gives more information about the topological distribution of the two forms of the enzyme. The nerve itself stains for both isozymes, although the stain for $\alpha(+)$ is qualitatively brighter. This is consistent with the hypothesis that the axolemma of the neurons express $\alpha(+)$, while the glia express $\alpha$. In contrast, the external sheath of the optic nerve, which is an extension of the pia-arachnoid and dura that joins the nerve at the point where it leaves the orbit, appears to stain brightly for the $\alpha$ form of the $\mathrm{Na}, \mathrm{K}$-ATPase. This implies a role for the enzyme in the regulation of the ionic environment of the nerve.
Previously available evidence was consistent with the hypothesis that the $\alpha(+)$ form of the $\mathrm{Na}, \mathrm{K}-\mathrm{ATP}$ ase was unique to myelinated axons, perhaps a specialization for anchoring the enzyme at nodes of Ranvier. The $\alpha(+)$ form could be purified from the axolemma of myelinated axons (Sweadner, 1979), and, as mentioned above, the optic nerve was shown in axonal transport experiments to have predominantly or only $\alpha(+)$ (Specht and Sweadner, 1984). In contrast, unmyelinated sympathetic and sensory neurons in culture had only $\alpha$ (Sweadner, 1979; J. M. Phillips and K. J. Sweadner, unpublished observations). In the present study, however, the unmyelinated fiber-filled plexiform layers of the retina stained for the $\alpha(+)$ form as brightly as did the ganglion cell axons. The $\alpha(+)$ form of the Na,KATPase has also been demonstrated to be expressed before myelination during the development of the central nervous system (Specht, 1984).

\section{Localization of the Na,K-ATPase in identified dissociated cells}

The use of enzymatically dissociated cells has some readily apparent limitations. First, large numbers of neuronal processes 
Table 1. Expression of the $\alpha(+)$ and $\alpha$ isozymes of the Na,K-ATPase in different classes of retinal cells

\begin{tabular}{lll} 
& \multicolumn{2}{l}{$\begin{array}{l}\text { Staining intensity for } \\
\text { Na,K-ATPase isozymes }\end{array}$} \\
\cline { 2 - 3 } Cell class & $\alpha(+)$ & $\alpha$ \\
\hline Photoreceptor & ++++ & ++ \\
Horizontal cell & ++++ & ++++ \\
Bipolar cell & + & -- \\
Amacrine cell & ++ & ++ \\
Ganglion cell & +++ & +++ \\
Müller cell & -- & ++++
\end{tabular}

a Staining intensity, as detected by the cross-adsorbed A2 and $\mathrm{K} 2$ antisera, was ranked qualitatively on the basis of simultaneous examination of different cell classes on the same slides. Brightest staining, ++++ . Faintest staining, + . Staining not greater than that seen with control rabbit serum, - -

are broken off from the cells during the dissociation procedure. These processes contribute to both plexiform layers, where much of the Na,K-ATPase is located. Second, portions of surrounding cells might, in principle, remain attached to the isolated cell of interest and contribute to immunocytochemical staining seen in the LM. We observed no spurious labeling with the monoclonal antibody markers, however, which indicates that adhering cellular material did not contribute significantly to the staining of dissociated cells. The correlation of monoclonal antibody stain with cells of recognizable morphology in fact serves to confirm the specificities that Barnstable et al. $(1983,1985)$ and Barnstable and Dräger (1984) have attributed to these antibodies. It has been observed by others that the external surface of the $\mathrm{Na}, \mathrm{K}-\mathrm{ATPase}$ is remarkably resistant to proteolysis in intact cells, whereas the cytoplasmic surface is very sensitive once proteases gain access to the cell interior (Knauf et al., 1974). The Na,K-ATPase in adhering cell fragments is likely to have been degraded during the cell dissociation.

Stirling and Sarthy (1985) have examined Na,K-ATPase distribution by ${ }^{3} \mathrm{H}$-ouabain autoradiography of dissociated photoreceptors and Müller cells from the turtle retina. They found that in the photoreceptors, grains corresponding to ouabain binding sites were localized over the cone inner segment ellipsoid and "fin" membrane, exactly as they appeared to be in retinal sections. Müller cells were also labeled. Furthermore, the density of grains in the dissociated cells was quantitatively similar to the number predicted on the basis of grain density in the retinal sections. This led to the conclusion that the enzymatic dissociation did not significantly damage the ouabain binding site, which is on the extracellular surface of the cell. Although they had enviable preservation of the cone photoreceptors, they did not report on any other retinal neurons.

Our results demonstrate that the two different isozymes of the $\mathrm{Na}, \mathrm{K}-\mathrm{ATPase}$ can be localized to identified cell classes in the retina (Table 1). It appears that some classes of neurons (the horizontal cells, amacrine cells, and ganglion cells) can express both forms of the Na,K-ATPase, which argues against the simpler hypothesis that one form is found in neurons and the other in glia. This corroborates the earlier observations that synaptosomal plasma membranes had equal amounts of the two forms (Sweadner, 1979), and that isolated neurons from the brain had both forms (Atterwill et al., 1984). It also provides a possible explanation for the appearance of a trace of the $\alpha$ form accompanying a much larger amount of the $\alpha(+)$ form in newly synthesized $\mathrm{Na}, \mathrm{K}$-ATPase axonally transported down the optic nerve (Specht and Sweadner, 1984). Roughly equal levels of stain for the two forms were found in dissociated retinal ganglion cell bodies, suggesting that there must be selective routing of the $\alpha(+)$ form to the axon.

The detection of only the $\alpha$ isozyme in Müller cells is con- sistent with observations on other glia in the CNS that have been found to express the $\alpha$ isozyme exclusively (Specht and Sweadner, 1984; Sweadner, 1979). Atterwill et al. (1984) concluded that their enriched glial preparations had both forms of the enzyme on the basis of ouabain sensitivity, but the possibility of contamination with neuronal elements was not definitively excluded. While the preponderance of our evidence suggests that glia have only $\alpha$, the recent report of the presence of $\alpha(+)$ in adipocytes (Lytton et al., 1985) indicates that $\alpha(+)$ can be expressed in at least some non-neuronal cells.

The very faint staining of amacrine cells and bipolar cells for the $\mathrm{Na}, \mathrm{K}$-ATPase implies a low concentration of the enzyme. This interpretation should be viewed with caution until confirmed by independent techniques, however, because we cannot rule out the possibility that these cell classes are more fragile than the others, and that some papain enters the cells and digests the $\mathrm{Na}, \mathrm{K}-\mathrm{ATPase}$ during the dissociation. The bipolar cells were the only cells in which only the $\alpha(+)$ form of the Na,K-ATPase was detected, but we are, of course, unable to rule out the presence of the $\alpha$ form of the enzyme at levels below the limit of detection by immunofluorescence.

Brilliant stain for both isozymes of the Na,K-ATPase was seen in a cell class that we believe to be horizontal cells on morphological grounds and because they did not stain with any of the other cell-specific antibodies. These cells probably contribute a large amount of the fluorescence seen in the outer plexiform layer. The detection of high concentrations of the $\mathrm{Na}, \mathrm{K}-\mathrm{ATPase}$ in horizontal cells is interesting in light of recent reports (Schwartz, 1982; Yazulla and Kleinschmidt, 1983) demonstrating $\mathrm{Na}^{+}$-dependent, $\mathrm{Ca}^{+2}$-independent, nonvesicular release of neurotransmitter by horizontal cells in amphibian and teleost fish retina. In these studies, intracellular $\mathrm{Na}^{+}$concentration appeared to be the factor modulating release of neurotransmitter, implying that rapid and fincly controlled fluxcs of $\mathrm{Na}^{+}$ might require high concentrations of the $\mathrm{Na}, \mathrm{K}-\mathrm{ATPase}$. It would be of considerable interest to determine whether mammalian horizontal cells behave similarly.

What now remains to be determined is the physiological roles of the two isozymes of the $\mathrm{Na}, \mathrm{K}-\mathrm{ATPase}$. A recent report by Lytton et al. (1985) provides evidence that in rat adipocytes, the $\alpha(+)$ isozyme of the Na,K-ATPase is selectively stimulated by insulin. It is possible that the two isozymes of this enzyme are differentially regulated by hormones and neurotransmitters.

\section{References}

Atterwill, C. K., V. J. Cunningham, and R. Balázs (1984) Characterization of $\mathrm{Na}, \mathrm{K}$-ATPase in cultured and separated neuronal and glial cells from rat cerebellum. J. Neurochem. 43: 8-18.

Barnstable, C. J., K. Akagawa, R. Hofstein, and J. P. Horn (1983) Monoclonal antibodies that label discrete cell types in the mammalian nervous system. Cold Spring Harbor Symp. Quant. Biol. 48: 863876.

Barnstable, C. J., and U. C. Dräger (1984) Thy-1 antigen: A ganglion cell specific marker in rodent retina. Neuroscience 11: 847-855.

Barnstable, C. J., R. Hofstein, and K. Akagawa (1985) A marker of early amacrine cell development in rat retina. Dev. Brain Res. 20: 286-290.

Berod, A., B. K. Hartman, and J. F. Pujol (1981) Importance of fixation in immunohistochemistry. Use of formaldehyde solutions at variable $\mathrm{pH}$ for the localization of tyrosine hydroxylase. J. Histochem. Cytochem. 29: 844-850.

Bignami, A., and D. Dahl (1979) The radial glia of Müller in the rat retina and their response to injury. An immunofluorescence study with antibodies to the glial fibrillary acidic (GFA) protein. Exp. Eye Res. 28: 63-69.

Dräger, U. C., D. L. Edwards, and J. Kleinschmidt (1983) Neurofilaments contain $\alpha$-melanocyte-stimulating hormone ( $\alpha$-MSH)-like immunoreactivity. Proc. Natl. Acad. Sci. USA 80: 6408-6412.

Dräger, U. C., D. L. Edwards, and C. J. Barnstable (1984) Antibodies 
against filamentous components in discrete cell types of the mouse retina. J. Neurosci. 4: 2025-2042.

Jørgensen, P. L. (1982) Mechanism of the $\mathrm{Na}^{+}, \mathrm{K}^{+}$pump. Protein structure and conformations of the pure $\left(\mathrm{Na}^{+}+\mathrm{K}^{+}\right)$-ATPase. Biochim. Biophys. Acta 694: 27-68.

Knauf, P. A., F. Proverbio, and J. F. Hoffman (1974) Chemical characterization and pronase susceptibility of the $\mathrm{Na}: \mathrm{K}$ pump-associated phosphorylation of human red blood cells. J. Gen. Physiol. 63: 305323.

Lytton, J., J. C. Lin, and G. Guidotti (1985) Identification of two molecular forms of $\left(\mathrm{Na}^{+}, \mathrm{K}^{+}\right)$-ATPase in rat adipocytes. Relation to insulin stimulation of the enzyme. J. Biol. Chem. 260: 1177-1184.

Osborn, M., W. W. Franke, and K. Weber (1977) Visualization of a system of filaments 7-10 nm thick in cultured cells of an epithelioid line (Pt K2) by immunofluorescence microscopy. Proc. Natl. Acad. Sci. USA 74: 2490-2494.

Rodieck, R. W. (1973) The Vertebrate Retina, Freeman, San Francisco.

Sarthy, P. V., and D. M. K. Lam (1979) Isolated cells from a mammalian retina. Brain Res. 176: 208-212.

Schwartz, E. A. (1982) Calcium-independent release of GABA from isolated horizontal cells of the toad retina. J. Physiol. (Lond.) 323: 211-227.

Specht, S. C. (1984) Development and regional distribution of two molecular forms of the catalytic subunit of the Na,K-ATPase in rat brain. Biochem. Biophys. Res. Commun. 121: 208-212.

Specht, S. C., and K. J. Sweadner (1984) Two different Na,K-ATPases in the optic nerve: Cells of origin and axonal transport. Proc. Natl. Acad. Sci. USA 81: 1234-1238.

Stahl, W. L., and D. G. Baskin (1984) Immunocytochemical local- izalion of $\mathrm{Na}^{+}, \mathrm{K}^{+}$adenosine triphosphatase in the rat retina. J. Histochem. Cytochem. 32: 248-250.

Stirling, C. E., and A. Lee (1980) $\left[{ }^{3} \mathrm{H}\right]$ Ouabain autoradiography of frog retina. J. Cell Biol. 85: 313-324.

Stirling, C. E., and P. V. Sarthy (1985) Localization of the Na-K pump in turtle retina. J. Neurocytol. 14: 33-47.

Sweadner, K. J. (1979) Two molecular forms of $\left(\mathrm{Na}^{+}+\mathrm{K}^{+}\right)$-stimulated ATPase in brain: Separation, and difference in affinity for strophanthidin. J. Biol. Chem. 254: 6060-6067.

Sweadner, K. J., and R. C. Gilkeson (1985a) Two isozymes of the $\mathrm{Na}, \mathrm{K}$-ATPase have distinct antigenic determinants. J. Biol. Chem. 260: 9016-9022.

Sweadner, K. J., and R. C. Gilkeson (1985b) Antibodies to the Na,KATPase: Localization of the Na,K-ATPase and a $135,000 M_{\mathrm{r}}$ protein to different structures in the rat retina. In The Sodium Pump. I. M Glynn and J. C. Ellory, eds., pp. 141-145, Company of Biologists, Cambridge, England.

Ueno, S., H. Mayahara, I. Tsukahara, and K. Ogawa (1980) Ultracytochemical localization of ouabain-sensitive, potassium dependent p-nitrophenylphosphatase activity in the guinea pig retina. I. Photoreceptor cells. Acta Histochem. Cytochem. 13: 679-694.

Ueno, S., H. Mayahara, I. Tsukahara, and K. Ogawa (1981) Ultracytochemical localization of ouabain-sensitive, potassium dependent $p$-nitrophenylphosphatase activity in the guinea pig retina. II. Neurons and Muller cells. Acta Histochem. Cytochem. 14: 186-206.

Yazulla, S., and J. Kleinschmidt (1983) Carrier-mediated release of GABA from retinal horizontal cells. Brain Res. 263: 63-75.

Zimmerman, W. F., F. J. M. Daeman, and S. L. Bonting (1976) Distribution of enzyme activities in subcellular fractions of bovine retina. J. Biol. Chem. 251: 4700-4704. 